\title{
An Overview of Motivation: The Challenges and the Importance of Motivation for Second Language Acquisition
}

\author{
Zahra Mahdikhani \\ Dept. of English, Science and Research Branch, Islamic Azad University \\ Zanjan, Iran \\ E-mail: Mahdikhani_teacher@yahoo.com
}

Received: April 2, 2016 Accepted: April 30, 2016 Published: May 2, 2016

doi:10.5296/jsel.v4i1.9407 URL: http://dx.doi.org/10.5296/jsel.v4i1.9407

\begin{abstract}
The importance of the learner's attitudes and motivation plays a major role for most psycholinguists, either in a language learning situation or in a second language acquisition context. A quick look at the major theories of language acquisition can be helpful to establish this. Krashen's monitor model argues attitudes and motivation most influential in unconscious language acquisition. The learner's motivational level acts as an affective filter on language intake (Krashen 1981, p. 102). In another model language learning begins when the learner feels motivated to communicate something to someone (see Carroll's conscious reinforcement model, 1981). Reinforcement takes place when the desired end is obtained. Bialystok's strategy model (1978) demonstrates that it can be assumed that learners will seek language exposure only if they feel motivated. Therefore, using their explicit and/or implicit knowledge, communication will take place. This study investigates the challenges and the importance of motivation for second language learning or SL acquisition.
\end{abstract}

Keywords: motivation, motivate student, attitude, interest 


\section{Introduction}

Motivation is one of the essential elements in language learning. Lightbown and Spada (1999) emphasise the importance of motivation. They stress that "The principal way that teachers can influence learners' motivation is by making the classroom a supportive environment in which students are stimulated, (and) engaged in (the) activities" (p.163). Motivated students can learn vocabulary successfully; unmotivated ones will have a lesser chance of success.

Student motivation is determined by his willingness and volition. Intrinsic motivation is animated by personal enjoyment, interest, or pleasure, nevertheless extrinsic motivation is dominated by reinforcement contingencies. Different components of motivation are a constellation of closely related beliefs, perceptions, values, interests, and actions. Motivation within individuals is rather variable across subject areas, and this domain specificity increases with age. Children create motivation later in their life, and as they grow up the stability of this relationship strengthens.

In general, children appear to enter school with high levels of intrinsic motivation, although motivation tends to decline as children progress through school. In spite of both positive and negative effects of studies, research suggests that motivation can be manipulated through certain instructional practices.

\subsection{Definition of Motivation}

Motivation refers to "the reasons underlying behavior" (Guay et al., 2010, p. 712). Paraphrasing Gredler, Broussard and Garrison (2004) broadly define motivation as "the attribute that moves us to do or not to do something" (p. 106). Intrinsic motivation is a kind of motivation that is animated by personal enjoyment, interest, or pleasure. As Deci et al. (1999) indicate "intrinsic motivation energizes and sustains activities through the spontaneous satisfactions inherent ineffective volitional action. It is manifest in behaviors such as play, exploration, and challenge seeking that people often do for external rewards" (p. $658)$.

For example, Gottfried (1990) explains academic motivation as enjoyment of school learning characterized by a mastery orientation; curiosity; persistence; task-endogeny; and the learning of challenging, difficult, and novel tasks" (p. 525). On the contrary, Turner (1995) discusses motivation to be synonymous with cognitive engagement, which he defines as "voluntary uses of high-level self-regulated learning strategies, such as paying attention, connection, planning, and monitoring” (p. 413).

\subsection{Relationship between Motivation and Engagement}

Although interest in engagement has increased recently, its distinction from motivation remains subject to debate. Maehr and Meyer (1997) state one conceptualization in which motivation has been though to find terms of the direction, intensity, and quality of one's energies, answering the question of "why am I doing this?" for a given behavior. In this regard, motivation is related to underlying psychological processes, including autonomy (e.g., Grolnick \& Ryan, 1987; Skinner et al., 1990), relatedness/ belonging (e.g., Goodenow, 1993a, 
1993b; Goodenow\& Grady, 1993), and competence (e.g., Schunk, 1991).

However, engagement is described as "energy in action, the connection between person and activity" (Russell, Ainley, \& Frydenberg, 2005, p.1). According to Reeve, et al. (2004), engagement reflects a person's active involvement in a task or activity. To illustrate this distinction as it pertains to reading tasks, Guthrie and Wigfield (2000) consider motivational aspects include(a) perceived reading competency; (b) perceived value of reading in order to obtain larger goals (better grades, parent/ teacher praise); and(c) perceived ability to succeed at the reading task, among others .

Therefore, motivation is necessary, but not sufficient for engagement. Although motivation is central to understanding engagement, the latter is a construct worthy of study in its own right. Furrer and colleagues (2006) stated the significance of viewing engagement within a motivational framework because engagement can change via cyclic interaction with contextual variables and influence later academic, behavioral, and social outcomes, which are the products of these context influenced changes in engagement.

It is clear from literature on motivation and engagement that "motivation is crucial to engagement because motivation is what activates behavior" (Guthrie \& Wigfield, 2000, p. 406). They express elements of literacy instruction that have been found to increase motivation for literacy learning such as learning goals that are co-created by teachers and students, the use of meaningful, real-world activities in the classroom, and the importance of choice, social collaboration, high-quality texts in educational tasks. Morrow (2001) demonstrates other variables to increase student motivation which include success on tasks, and a stimulating, literacy-rich environment in the classroom.

\subsection{Expectations for Success: Motivation and Learning}

There is a direct relationship between motivation to learn and an eagerness to learn and a commitment to learning. Students who are motivated to learn can be observed working thoroughly on a task, seeking under-standing, and persevering when they encounter challenges. Noting that motivation to learn is more than simply excitement about a particular topic is quite important; however being motivated to learn refers to the degree to which students are dedicated to and engaged in learning. A willingness to think through problems and work through challenges to achieve mastery of a concept or skill goes beyond simply having fun during learning.

Students' expectations for success can be attributed to different factors, and some of these factors are related to students' beliefs about intelligence and their capacity to improve their intellectual abilities. According to Carol Dweck (1986), a motivation theorist, students have different beliefs about the nature of their intelligence: unlike the imagination of some people about the fixedness of intelligence, others believe it can be developed by working hard on something. Schools foster or impede these beliefs to the extent that they emphasize effort rather than ability in their judgments about students and their attributions of causes of success (e.g.," smartness" vs. "hard work").These beliefs can promote or hinder students' learning efforts in the classroom (Dweck,1986). 
Students are more likely to be interested in a task that they find personally relevant or valuable. Similarly, teachers must design activities that are related, where possible, to students' lives or current events (Stipek, 2002). Additionally, students are more likely to be intrigued by problems that are realistic and challenging. In particular, they can stimulate their interest when the skills they are developing will have real-world significance (Pintrich \& Schunk, 1996).

Finally, tasks become more interesting the more realistic and challenging they are. There is a unit helping students learn the features of a short story motivates and engages them, and it makes them apply those features in their own creation of a story than by a lesson that asks them to memorize the meaning of setting, plot, character, etc. Students who have to use concepts of ratio and proportion by building a scale model or altering and using a recipe are more likely to be engaged and to learn the concepts for future applications than if they completed a set of paper problems only (Brophy, 1987).

\subsection{Technology and its Effect on Motivation and Retention}

Sanacore (2008) stated that students' intrinsic motivation must be encouraged by teachers in a traditional classroom. According to Woolfolk-Hoy and Hoy (2009) intrinsic motivation stems from factors such as interest or curiosity. On the other hand, extrinsic motivation focuses on rewards or incentives. Teachers must encourage and challenge their students in order to motivate, (Sanacore, 2008). Students presented with too easy or too difficult material will eventually become bored and unmotivated. In a traditional classroom, teachers must differentiate activities in order to place some power into the hands of the students (Sanacore). This freedom has a positive influence on the motivation for a student who is unwilling to participate. There must always be great motivators who encourage students to love learning and help students maintain high self-efficacy beliefs (Linnenbrink and Pintrich, 2003). This often proves to be the most difficult task for some teachers.

To motivate students, teachers of all subjects may encounter a challenging task, in fact they must rely on what interests students and what they already know and with which they are successful creating activities. Students must enjoy those activities created by teachers, and they must positively respond to them. Introducing technology infused lessons may prove to be a beneficial motivator for every grade level. Digital natives respond well to technology-infused activities because of their familiarity with technology (Prensky, 2001).

Students' motivation is positively affected by technology and teachers' motivation (Atkinson, 2000). Teachers should make conscious efforts to create activities that encompass some form of technological tool due to students' positive response to technology and motivation created by technology for them. Motivated students will be more likely to perform at their highest levels because of the opportunities that their teachers have made available.

\subsection{Challenges in Assessing Motivation}

According to Turner (1995), assessing motivation includes several challenges, particularly in children. First, cognitive aspects of motivation, such as achievement affect, interests, and goals are not directly observable. Second, self-report measures of motivation tend to produce 
generalized responses rather than responses relating to specific instructional events or tasks. For example, children may be asked to respond to a statement such as I like work that is hard. Representing the type of generalized response that is commonly sought in self-report instruments is difficult for children. Children tend to instead interpret just-experienced events rather than summarize across a range of situations and content areas.

Third, self-report measures may be developmentally inappropriate for children, who have a tendency toward positive response bias because they are more inclined than older students to be optimistic. As Turner explains, children hardly separate their efforts and intentions from their real manner due to its difficulty. Thus, children who intend to exert a lot of effort may mistakenly believe that they have actually done so. Another source of positive response is social desirability to which children are highly susceptible.

\section{Conclusion}

Based on the discussion, motivation is obviously a very important and effective factor in the field of learning language. Therefore, not only the language teachers and lecturers should discover, realize, and pay attention to the personality of their students, but also they should be informed about motivation, its high significance, and its types. This article has highlighted important role of motivation in which teachers can affect their students' learning. To engage in meaningful learning endeavors, students need to feel they have the ability to succeed, and they need to feel personally interested in the work. In the classroom, teachers have multiple opportunities to communicate to students that they have enormous potential to learn and succeed. If teachers try to emphasize their students' effort, recognize their progress and improvement, and minimize making comparisons among them, teachers can help students gain the confidence they need to feel motivated to learn. Moreover, by relating the subject matter to students' own lives, emphasizing big concepts, and allowing students to pursue areas of curiosity, teachers can help students develop an authentic interest in learning different types of material.

\section{References}

Atkinson, E. S. (2000). An investigation into the relationship between teacher motivation and pupil motivation. Educational Psychology, 20(1), 45-57.

Bialystock, E. (1978). A theoretical model of second language learning. Language learning 28, 69-83.

Brophy, J. (1987). On motivating students. In D. Berliner, \& B. Rosenshine (Eds.), Talks to teachers (pp. 201-245). New York: Random House.

Carroll, J. B. (1981). Conscious and automatic processes in language learning. Canadian Modern Language Review, 37, 462-74.

Deci, E. L., Koestner, R., \& Ryan, R. M. (1999). A meta-analytic review of experiments 
examining the effects of extrinsic rewards on intrinsic motivation. Psychological Bulletin, 125(6), 627-668.

Dweck, C. (1986). Motivational processes affecting learning. American Psychologist, 41, 1040-1048.

Furrer, C. J., Skinner, E., Marchand, G., \& Kindermann, T. A. (2006, March). Engagement vs. disaffection as central constructs in the dynamics of motivational development. Paper presented at the annual meeting of the Society for Research on Adolescence, San Francisco, CA.

Goodenow, C. (1993a). The psychological sense of school membership among adolescents: Scale development and educational correlates. Psychology in the Schools, 30, 79-90.

Goodenow, C. (1993b). Classroom belonging among early adolescent students: Relationship to motivation and achievement. Journal of Early Adolescence, 13(1), 21-43.

Goodenow, C., \& Grady, K. E. (1993). The relationship of school belonging and friends' values to academic motivation among urban adolescent students. Journal of Experimental Education, 62, $60-71$.

Gottfried, A. E. (1990). Academic intrinsic motivation in young elementary school children. Journal of Educational Psychology, 82(3), 525-538.

Grolnick, W. S., \& Ryan, R. M. (1987). Autonomy in children's learning: An experimental and individual differences investigation. Journal of Personality and Social Psychology, 52, 890-898.

Guay, F., Chanal, J., Ratelle, C. F., Marsh, H. W., Larose, S., \& Boivin, M. (2010). Intrinsic, identified, and controlled types of motivation for school subjects in young elementary school children. British Journal of Educational Psychology, 80(4), 711-735.

Guthrie, J. T., \& Wigfi eld, A. (2000). Engagement and motivation in reading. In M. L. Kamil, \& P. B. Mosenthal (Eds.), Handbook of reading research (Vol. III, pp. 403-422). Mahwah, NJ: Erlbaum.

Krashen, S. D. (1981). Second language acquisition and second language learning. New York: Pergamon.

Lightbown, P. M., \& Spada, N. (1999). How languages are learned (Rev. ed.). Oxford: Oxford University Press.

Linnenbrink, E. A., \& Pintrich, P. R. (2002). Motivation as an enabler for academic success. School Psychology Review, 31(3), 313-327.

Maehr, M. L., \& Meyer, H. A. (1997). Understanding motivation and schooling: Where we've been, where we are, and where we need to go. Educational Psychology Review, 9, 371-408.

Morrow, L. M. (2001). Literacy development in the early years: Helping children read and 
write (4h ed.). Boston: Allyn \& Bacon.

Pintrich, P. R., \& Schunk, D. H. (1996). Motivation in Education: Theory, Research, and Application. Upper Saddle River, N.J.: Merrill.

Prensky, M. (2001, October). Digital natives, digital immigrants. On the Horizon, 9(5), $\begin{array}{llll}\text { Retrieved November } & \text { 19, 2009, from }\end{array}$ http://www.hfmboces.org/HFMDistrictServices/TechYES/PrenskyDigitalNatives.pdf

Reeve, J., Jang, H., Carrell, D., Jeon, S., \& Barch, J. (2004). Enhancing students' engagement by increasing teachers' autonomy support. Motivation and Emotion, 28, 147-169.

Russell, V. J., Ainley, M., \& Frydenberg, E. (2005). Schooling issues digest: Student motivation and engagement. Retrieved November 9, 2005, from http://www.dest.gov.au/sectors/school education/publications resources/schooling issues digest/schooling issues digest motivation engagement.htm

Sanacore, J. (2008, September 1). Turning Reluctant Learners into Inspired Learners. Clearing House: A Journal of Educational Strategies, Issues and Ideas, 82(1), 40-44.

Schunk, D. H. (1991). Self-efficacy and academic motivation. Educational Psychologist, Special Issue: Current Issues and New Directions in Motivational Theory and Research, 26(3-4), 207-231.

Skinner, E. A., Wellborn, J. G., \& Connell, J. P. (1990). What it takes to do well in school and whether I've got it: A process model of perceived control and children's engagement and achievement in school. Journal of Educational Psychology, 82, 22-32.

Stipek, D. J. (2002). Maintaining positive achievement related beliefs (Chapter 7) and Maximizing intrinsic motivation, academic values and learning goals (Chapter 11). In Motivation to learn: Integrating theory and practice (pp. 97-119, pp. 173-193). Boston: Allyn \& Bacon.

Turner, J. C. (1995). The influence of classroom contexts on young children's motivation for literacy. Reading Research Quarterly, 30, 410-441.

Woolfolk-Hoy, A., \& Hoy, W. K. (2009). Instructional leadership: A research-based guide to learning in schools (3rd ed.) Boston: Pearson.

\section{Copyright Disclaimer}

Copyright for this article is retained by the author(s), with first publication rights granted to the journal.

This is an open-access article distributed under the terms and conditions of the Creative Commons Attribution license (http://creativecommons.org/licenses/by/3.0/). 